Jurnal Pendidikan Jasmani Kesehatan dan Rekreasi(Penjaskesrek)

Volume 6, Nomor 1, Januari 2019

\title{
PERMAINAN TRADISIONAL BUAH PAL MIX DALAM PEMBELAJARAN PENJASORKES UNTUK SISWA SEKOLAH DASAR NEGERI KELAS IV DAERAH PERBATASAN KECAMATAN ENTIKONG
}

\author{
Yulita $^{1}$, Sukardi $^{2}$ \\ ${ }^{1}$ Dosen STKIP Melawi (Kampus Entikong) \\ ${ }^{2}$ Dosen STKIP Melawi
}

Jln. Kuari Yayasan Lintas Batas Kecamatan Entikong Kabupaten Sanggau

Jl. RSUD Melawi km. 04 Kec. Nanga Pinoh Kab. Melawi Kalimantan Barat Email: buyulita79@gmail.com,pakardi83@gmail.com

\begin{abstract}
The research aims to produce a Pal Mix game model that can be used as a guide: 1) knowing the effectiveness of the Pal Mix traditional game model 2) knowing the acceptability of the traditional Pal Mix game model. The research method used is product development in the form of Pal Mix game model for grade IV elementary school students conducted by stages. 1) Development of descriptive and survey research, 2) Develop product design, 3) Expert validation, 4) Small-scale trials, 5) Test development products. The results of this study are in the form of Pal Mix which is used as physical education learning media. The traditional Pal Mix game in physical education can improve psychomotor, cognitive and affective aspects based on the results of research conducted in elementary school, namely the effectiveness of Pal Mix game products to get a positive response from students in physical education.
\end{abstract}

Keywords: Traditional game, Pal Mix

Abstrak: Penelitian ini bertujuan untuk menghasilkan model permainan $\mathrm{Pal}$ Mixyang dapat digunakan sebagai panduan: 1) mengetahui efektivitas model permainan tradisional Pal Mix 2) mengetahui keterterimaan model permainan tradisional Pal Mix. Metode penelitian yang digunakan adalah pengembangan produk berupa model permainan Pal Mix untuk siswa SD kelas IV dilakukan dengan tahapan. 1) Pengembangan penelitian deskriftip dan survei, 2) Menyusun desain pruduk, 3) Validasi ahli, 4) Uji coba skala kecil, 5) Menguji produk pengembangan.Hasil penelitian ini berupa permainan Pal Mixyang digunakan sebagai media pembelajaran penjasorkes. Permainan tradisional Pal Mixdalam pembelajaran penjasorkes dapat meningkatkan aspek psikomotor, kognitif dan afektif berdasarkan hasil penelitian yang dilaksanakan di SD yaitu keefektifan produk permainan $\mathrm{Pal}$ Mixmendapat respon positif siswa dalam pembelajaran penjasorkes.

Kata Kunci: Permainan Tradisional, Pal Mix. 
Dendidikan Jasmani, olahraga, dan merupakan salah satu mata pelajaran yang diajarkan dari jenjang pendidikan dasar sampai pendidikan menengah atau kejuruan, pendidikan dasar merupakan pondasi untuk pendidikan selanjutnya. Sekolah Dasar (SD) merupakan dunia anak-anak yang identik dengan bermain melalui permainan, anak mempelajari berbagai keterampilan motorik, keterampilan bersosialisas, sekaligus memperoleh kesenangan dan hiburan. Anak-anak dan aktivitas bermain merupakan dua subjek yang telah menyatu dalam satu kesatuan yang tidak dapat dipisahkan. Animo anak-anak dalam melakukan kegiatan olahraga menunjukkan gejala penurunan. Hal ini disebabkan semakin intensifnya persaingan pendidikan dan banyaknya hiburan di era modern seperti televisi, komputer, vcd, playstation, dan lain-lain. Sementara aktivitas anak dalam bermain di lapangan terbuka semakin terbatasi dengan sarana yang menyempit dan suasana budaya bermain yang makin terkikis. Pendidikan jasmani adalah wahana untuk mendidik anak, dan para ahli sepakat, bahwa pendidikan jasmani merupakan "alat" untuk membina anak muda agar kelak mereka mampu membuat keputusan terbaik tentang aktivitas jasmani yang dilakukan dan menjalani pola hidup sehat di sepanjang hayatnya. Tujuan ini akan dicapai melalui penyediaan pengalaman langsung dan nyata berupa aktivitas jasmani. Aktivitas jasmani itu dapat berupa permainan atau olahraga yang terpilih. Olahraga tradisional sering dijadikan sebagai jenis permainan yang memakai ciri kedaerahan asli serta disesuaikan dengan tradisi budaya setempat.

Permainan tradisional dikenal memiliki beberapa keunggulan dibanding permainan modern pada masa kini. Permainan tradisional dapat memperkenalkan, melestarikan, sekaligus meningkatkan kecintaan terhadap warisan budaya bangsa dan nilai-nilai luhur yang terkandung di dalamnya. Pada era globalisasi kini beberapa pakar pendidikan Indonesia berusaha untuk menghidupkan dan melestarikan permainan tradisional di tengah gencarnya pengaruh budaya dan teknologi modern, (Pratiwi, 2015). 
Permainan tradisional adalah salah satu materi yang terdapat pada mata pelajaran penjasorkes yang saat ini sudah mulai ditinggalkan dan jarang dimainkan, anak-anak sekarang beralih ke permainan modern atau canggih seperti playstation, video game, dan game online. Beragam permainan tradisional memang mampu menjadi media untuk mengoptimalkan berbagai kecerdasan kognitif, kecerdasan sosial, kecerdasan musikal, kecerdasan kinestetik, kecerdasan linguistik, kecerdasan spiritual, hingga mengajarkan berbagai nilai positif dan menyehatkan badan (Achroni, 2012:6). Di dalam masyarakat peran penting dalam permainan tradisional, perlu kita kembangkan demi ketahanan budaya bangsa, karena kita menyadari bahwa kebudayaan merupakan nilai-nilai luhur bagi bangsa indonesia, untuk diketahui dan dihayati tata cara kehidupannya sejak dahulu

Buah Pal adalah permainan tradisional yang ada di daerah perbatasan Entikong, nama lainnya yaitu kelereng atau Guli. Buah Pal merupakan satu dari berbagai macam permainan tradisional yang ada di daerah Entikong, permainan ini biasanya dimainkan oleh minimal 2 anak. Namun makin banyak anak yang ikut bermain, permainan akan semakin seru selain itu Buah Pal sering dimainkan anak-anak di waktu luang, anak-anak senang bermain Buah Pal.

\section{Permainan Buah Pal dapat} dilakukan di atas tanah, ubin, permukaan beraspal, atau permukaan semen, Buah Pal identik sebagai mainan anak laki-laki meski begitu Buah Pal bisa dimainkan anak laki-laki maupun perempuan. Buah Pal Mix (campur) adalah permainan Buah Pal dicampur atau digabungkan dengan aktivitas membidik, menyusun potongan puzzle, berlari, melompat, dan melempar. Alasan pemilihan permainan Buah Pal Mix karena anakanak suka dan senang bermain Buah Pal, permainan Buah Pal mix aman dimainkan untuk anak-anak, alat-alat yang digunakan relatif murah. Selain itu, Buah Pal mix dikembangkan untuk meningkatkan aspek kognitif, psikomotor, dan afektif serta terciptanya pembelajaran dengan prinsip PAIKEM. 
Penelitian pengembangan ini bertujuan untuk menghasilkan model permainan tradisional Buah Pal Mix yang dapat digunakan sebagai salah satu cara guru agar tujuan pembelajaran penjasorkes di SDN tercapai.

Permainan tradisional adalah bentuk kegiatan permainan atau olahraga yang berkembang dari suatu kebiasaan masyarakat tertentu. Pada perkembangan selanjutnya permainan tradisional sering dijadikan sebagai jenis permainan yang memiliki ciri kedaerahan asli serta disesuaikan dengan tradisi budaya setempat. Kegiatannya dilakukan baik secara rutin maupun sekali-kali dengan maksud untuk mencari hiburan dan mengisi waktu luang setelah terlepas dari aktivitas rutin seperti sekolah dan belajar. Dalam pelaksanaannya permainan tradisional dapat memasukkan unsur-unsur permainan rakyat dan permainan anak ke dalamnya (Achroni, 2012:92).

Zuhriyah (2015) mengatakan bahwa kelereng merupakan jenis mainan yang umumnya sudah sangat tua. Mainan ini telah dikenal sejak Zaman Mesir Kuno, 176 tahun 3000 sebelum masehi. Pada zaman itu kelereng dibuat dari batu atau tanah liat. Sementara itu, kelereng tertua koleksi The British Museum di London berasal dari tahun 2000-1700 SM. Kelereng tersebut ditemukan di kreta pada situs Minoanof petsofa dan saat ini umumnya kelereng dibuat dari kaca. Penerapan permainan tradisional (balap karung, lompat tali dan kelereng) dapat meningkatkan kemampuan sosial dan emosional.

Buah Pal Mix istilah lainya adalah guli atau kelereng, permainan ini telah dikembangkan dan dimodifikasi peneliti sebagai alternatif untuk menjawab permasalahan yang dihadapi dalam pembelajaran penjasorkes, yaitu siswa tidak memperoleh materi permainan tradisional oleh gurunya. Guli (kelereng) dibidik, Mix (campur) adalah permainan dicampur atau digabungkan dengan aktivitas membidik, menyusun potongan puzzle, berlari, melompat, dan melempar. Buah Pal Mix ini diarahkan agar guru penjasorkes memberikan materi permainan tradisional kepada siswa dan ikut melestarikan permainan daerah 
yang sekarang ini sudah hampir ditinggalkan anak-anak

Kelebihan produk Buah PalMix pada pembelajaran penjasorkes untuk siswa SD Antara lain: 1) Menyajikan permainan tradisional Buah PalMix (menyusun puzzle, lari, lempar, dan lompat) yang dikemas secara menarik sehingga siswa sekolah dasar bergerak aktif. 2) Peraturan permainan dan alatalat yang digunakan di sesuaikan dengan kebutuhan siswa sekolah dasar. 3) Permainan tradisional Buah PalMix aman dimainkan dan alat-alat yang digunakan relatif murah. 4) Pengembangan permainan tradisional Buah Pal Mix dapat membantu guru Penjasorkes dalam proses pembelajaran di sekolah khususnya untuk bahan ajar alternatif dan variasi mengajar pada materi permainan tradisional serta untuk meningkatkan kebugaran jasmani siswa peningkatan dalam setiap ranah tujuan pendidikan yaitu aspek psikomotor, kognitif, dan afektif. Penelitian pengembangan biasanya disebut pengembangan berbasis penelitian (research-based development) merupakan jenis penelitian yang bertujuan untuk menghasilkan produk baru melalui proses pengembangan. Penelitian pengembangan merupakan jenis penelitian yang digunakan dalam memecahkan persoalan praktis, daam bidang ilmu sosial, ilmu alam, teknik, dan dunia pendidikan. Kegiatan penelitian diintegrasikan selama proses pengembangan produk. Oleh sebab itu, di dalam penelitian ini perlu memadukan beberapa jenis metode penelitian, antara lain jenis penelitian survei dengan eksperimen atau action research dan evaluasi (Multiyaningsih, 2012:161).

\section{METODE PENELITIAN}

Penelitian pengembangan biasanya disebut pengembangan berbasis penelitian (research-based development) merupakan jenis penelitian yang bertujuan untuk menghasilkan produk baru melalui proses pengembangan. Penelitian pengembangan merupakan jenis penelitian yang digunakan dalam memecahkan persoalan praktis, dalam bidang ilmu sosial, ilmu alam, teknik, dan dunia pendidikan. Kegiatan penelitian diintegrasikan selama proses pengembangan produk, oleh sebab itu 
di dalam penelitian ini perlu memadukan beberapa jenis metode penelitian, antara lain jenis penelitian survei dengan eksperimen atau action research dan evaluasi (Multiyaningsih, 2012:161).

\section{Prosudur pengembangan}

Rancangan

model pengembangan penelitian ini dilakukan dalam enam tahap. Berdasarkan beberapa pendapat tersebut maka prosedur yang digunakan dalam pengembangan model permainan Buah Pal Mix untuk pembelajaran penjasorkes di sekolah dasar ini meliputi enam tahap yaitu:

Tahap pertama, pengembangan penelitian deskriftip dan survei kepada guru dan siswa SD. Survei bertujuan untuk memperoleh data analisis pelaksanaan pembelajaran permainan tradisional kepada guru dan siswa, persepsi guru dan siswa tentang pembelajaran tradisional di sekolah dasar. Analisis kebutuhan tentang pengembangan materi permainan tradisional melalui Buah Pal Mix di SD.

Tahap kedua, langkah penyusunan desain produk awal pengembangan Buah Pal Mix di SD.
Validasi materi kepada ahli yang terlibat dalam penelitian antara lain: 1) ahli pendidikan jasmani olahraga dan kesehatan, 2) ahli permainan tradisional, 3) guru penjasorkes. Hasil dari validasi kemudian dikaji untuk memperbaiki rancangan model sebelum diujicobakan.

Tahap ketiga, validasi produk kepada ahli yang terlibat dalam penelitian antara lain: 1) ahli pendidikan jasmani olahraga dan kesehatan: 2) ahli permainan tradisional:. Hasil dari validasi para ahli yang kemudian dikaji untuk memperbaiki rancangan model sebelum diujicobakan.

Tahap keempat,Uji coba produk pengembangan menggunakan uji coba skala kecil yang melibatkan 3 guru Penjasorkes dan 36 siswa SD kelas IV responden terlebih dahulu. Uji coba skala kecil bermanfaat untuk menganalisis kendala yang mungkin dihadapi dan berusaha untuk mengurangi kendala tersebut pada saat penerapan model berikutnya. Revisi produk pertama dilakukan berdasarkan hasil uji coba produk tahap 
Tahap kelima, melakukan desain penelitian eksperimental yang bertujuan untuk menguji produk pengembangan Buah Pal Mix yang dikembangkan untuk keaktifan, keefektifan pembelajaran, kemenarikan untuk pelaksanaan materi permainan tradisional dalam pembelajaran penjasorkes di SD. Kemudian melakukan uji coba lapangan dengan skala lebih besar yang melibatkan responden yaitu 3 guru Penjasorkes dan 60 siswa SD kelas IV. Revisi produk kedua dilakukan setelah uji coba produk tahap 2.Tahap keenam, penerapan model Buah Pal Mix untuk materi permainan tradisional dalam pembelajaran Penjasorkes di SD, pada tahap ini pengumpulan data dilaksanakan dengan instrumen yaitu berupa kuisioner yang kemudian dilaporkan dan di analisis secara keseluruhan sehingga dapat menyimpulkan untuk keefektifan produk dan terciptanya produk Buah Pal Mixyang sesuai untuk materi permainan tradisional dalam pembelajaran Penjasorkes di SD.

Tehnik Pengumpulan Data
Metode Pengumpulan data ialah teknik atau cara-cara yang dapat digunakan oleh peneliti untuk mengumpulkan data. Metode (cara atau teknik) menunjuk suatu kata yang abstrak dan tidak diwujudkan dengan benda, tetapi hanya dapat dilihatkan penggunaannya melalui: angket, kuisioner, wawancara pengamatan, ujian (tes), dan dokumentasi (Riduwan, 2007:24). Instrumen dalam penelitian ini adalah kuesioner yang disusun oleh peneliti yang selanjutnya dijadikan alat penilaian dari 2 orang pakar/ahli untuk merevisi produk yang akan dikembangkan. Setelah mendapat persetujuan dari tim ahli (judges) kemudian diujicobakan pada skala kecil untuk dapat mengetahui tingkat validitas dan reliabilitas, selanjutnya dilakukan tes yang sebenarnya pada tes skala besar.

\section{HASIL DAN PEMBAHASAN \\ Berdasarkan penentuan reliabilitas keterterimaan produk siswa untuk penelitian ini maka diperoleh data hasil perhitungan korelasi dari 10 butir soal, koefisien reliabilitasmenggunakan Guttman Split-Half Coefficientuntuk 60 siswa}


sebagai responden yaitu 0,589. Dapat disimpulkan hasil reliabilitas untuk respon siswa dikatakan reliabel karena rhitung lebih besar dari $r$ tabel yaitu 0,235 dengan taraf signifikan 5\%. Jumlah soal yang valid yaitu 8 soal, sedangkan yang tidak valid 2 soal (soal 9, 10) dengan rhitung terendah yaitu 0.060. Sesuai kriteria reliabilitas, maka dapat disimpulkan bahwa data butir soal yang valid mempunyai reliabilitas tinggi.Berdasarkan penentuan reliabilitas keterterimaan produk guru untuk penelitian ini makadiperoleh data hasil perhitungan korelasi dari 20 butir soal, koefisien reliabilitas menggunakan Guttman Split-Half Coefficientuntuk 2 guru sebagai responden yaitu 0,956. Dapat disimpulkan hasil reliabilitas untuk respon siswa dikatakan reliabel karena rhitung lebih besar dari $\mathrm{r}$ tabel yaitu 0,950 dengan taraf signifikan 5\%. Jumlah soal yang valid yaitu 16 soal, sedangkan yang tidak valid 4 soal (soal $17,18,19,20)$ dengan rhitung terendah yaitu 0.697. Sesuai kriteria reliabilitas, maka dapat disimpulkan bahwa data butir soal yang valid mempunyai reliabilitas tinggi.

\section{Pembahasan}

Permainan Tradisional Pal Mix di kemas secara menarik yang di dalamnya terdapat unsur (menyusun puzzle, lari, lempar, dan lompat) agar siswa sekolah dasar bergerak aktif. Peraturan permainan dan alat-alat yang digunakan di sesuaikan dengan kebutuhan siswa sekolah dasar.Permainan tradisional PalMix aman dimainkan dan alat-alat yang digunakan relatif murah.Pengembangan permainan tradisional PalMix dapat membantu guru Penjasorkes dalam proses pembelajaran di sekolah khususnya untuk bahan ajar alternatif dan variasi mengajar pada materi permainan tradisional serta untuk meningkatkan kebugaran jasmani siswa peningkatan dalam setiap ranah tujuan pendidikan yaitu aspek psikomotor, kognitif, dan afektif.

Berdasarkan langkah-langkah penelitian pengembangan untuk menghasilkan produk yang telah dilakukan, maka di dapat produk akhir berupa model permainan tradisional PalMix yang sesuai dengan karakterisitik siswa sekolah dasar. 
Indikator keberhasilan produk ini ialah berupa lembar penilaian hasil pengamatan terhadap seluruh subyek yang diujicobakan dalam penelitian ini.penghitungan uji coba skala luas keterterimaan produk terhadap 60 siswa hasil akhir respon positif termotivasinya siswa dalam permainan tradisional, hal ini dapat diartikan bahwa sangat positif keterterimaan permainan tradisional PalMix sebagai pembelajaran yangmenarik, menyenangkan dan juga sebagai bahan ajar alternatif guru penjasorkes dalam pelaksanaan pembelajaran penjasorkes di sekolah terutama untuk siswa kelas IV SD

\section{SIMPULAN}

Berdasarkan hasil penelitian dan pembahasan tentang pengembangan permainan tradisioanl Pal Mix untuk pembelajaran penjasorkes di SD, maka dapat disimpulkan: 1) Permainan tradisional Pal Mix merupakan bahan alternatif untuk guru penjasorkes dalam memberikan materi permainan tradisional yang bertujuan agar siswa tidak melupakan permainan tradisional daerah mereka. 2) Permainan tradisional Pal Mix dalam pembelajaran penjasorkes dapat meningkatkan aspek psikomotor, kognitif dan afektif berdasarkan hasil penelitian yang dilaksanakan di $2 \mathrm{SD}$ yaitu keefektifan produk permainan tradisioanl Pal Mix mendapat respon positif siswa dalam pembelajaran penjasorkes sebesar $95,25 \%$, sedang respon negative sebesar $4,75 \%$. Jadi kesimpulan keefektifan produk permainan tradisional Pal Mix dalam kategori sangat baik. 3) Permainan tradisional Pal Mix dalam pembelajaran penjasorkes dapat dijadikan sebagai bahan alternatif guru dalam pelaksanaan pembelajaran berdasarkan hasil penelitian yang dilaksanakan di 2 SD yaitu hasil pengisian angket respon terhadap guru dianalisis dengan dipersentasekan dan diperoleh bahwa 92,5\% guru Penjasorkes memberikan respon positif dan 7,5\% memberikan respon negatif berarti guru Penjasorkes yang memberikan respon positif lebih dari $81 \%$ maka dapat dikategorikan bahwa respon guru Penjasorkes terhadap pengembangan permainan tradisional Pal Mix sebagai alternatif pembelajaran dalam kategori sangat baik. 4) 
Permainan tradisional Pal Mix dalam pembelajaran penjasorkes dapat meningkatkan denyut nadi siswa putri sebesar $68,60 \%$ dan siswa putra sebesar $69,16 \%$.

\section{DAFTAR PUSTAKA}

Achroni, K. 2012. Mengoptimalkan Tumbuh Kembang Anak Melalui Permainan Tradisional. Yogyakarta: Javalitera.

Mulyatiningsih, E. 2012 Metode Penelitian Terapan Bidang Pendidikan. Bandung: Alfabeta.

Pratiwi, Y. 2015. "Upaya Meningkatkan Kemampuan Motorik Kasar (Keseimbangan Tubuh) Anak Melalui Permainan Tradisional Engklek Di Kelompok B Tunas Rimba Ii Tahun Ajaran 2014/2015”. Jurnal Penelitian PAUDIA. Volume 3 Nomor 2 Tahun 2014. ZuhriyahIin. 2015. "Upaya Meningkatkan Keseimbangan Tubuh Anak Melalui Permainan

Tradisional Kelereng Sendok Pada Kelompok B Tk Mardisiwi Ii Tuksongo Temanggung Tahun Ajaran 2015/2016”. Jurnal
PAUDIA, Volume 4 Nomor 2

Tahun 2015. 
37 IJPJKR, p-ISSN:2252-8148, e-ISSN:2579-4604 